\title{
Codification of Company Law: Taking Stock of the Companies Act 2006
}

\author{
Deirdre Ahern*
}

\begin{abstract}
The Companies Act 2006 was presented by the Labour Government of the day as a tour de force in legislative drafting, pursuing a multi-faceted policy agenda designed to appeal to a range of stakeholders. This article considers the lengthy review process which led to the drafting and enactment of the Companies Act 2006 including the underlying work of the Company Law Review and the English and Scottish Law Commissions which laid the groundwork for the drafting of the Act. The Act is evaluated at a macro-level from the perspective of its avowed objectives as both a codifying and reforming Act and one which was designed to advance a pro-enterprise mandate. The article also examines the plain language agenda which was designed to make company law more accessible, as well as how the transfer of the common law and equitable duties of directors to statute was handled at drafting stage. In this regard, subsections 170(3) and (4) of the Companies Act 2006 contain a unique set of instructions in relation to the replacement of the duties albeit with a dissonant instruction to interpret the new statutory duties with regard to the rules and principles they replace, something which proved controversial during the Parliamentary process. The manner in which the courts in the intervening years have approached the interpretation of these statutory duties is therefore examined.
\end{abstract}

\section{INTRODUCTION}

The Companies Act 2006 with its 1300 provisions and multiple schedules was quite simply the largest Act of Parliament yet to be contended with. As Professor Paul Davies commented, ' $[\mathrm{u}]$ ndoubtedly, it is long, but ... length is not necessarily the enemy of good law.' The legislation involved consolidation of various disparate provisions previously contained in a range of legislative sources. ${ }^{2}$ However, as reform was involved, the process went beyond a simple restatement of the law and in some instances involved reform and the transfer of common law principles to a statutory setting. This type of codification went well beyond that in any companies legislation that had gone before.

\footnotetext{
* Assistant Professor, School of Law, Trinity College Dublin. E-mail: dahern@tcd.ie. The author is grateful to the Statute Law Society for the invitation to present a version of this paper at its conference Statute Law and Alternative Solutions: Codification, Restatement, Common Law at the Houses of Parliament, London on 15 November 2013.

P. L. Davies, Gower and Davies' Principles of Modern Company Law (8th ed., Sweet \& Maxwell, 2008) at p.vi.

The Companies Act 2006 involved the replacement of much of the Companies Acts 1985, the Companies Act 1989 and the Companies (Audit, Investigations and Community Enterprise) Act 2004.
}

(C) The Author 2014. Published by Oxford University Press. All rights reserved. For permissions, please e-mail: journals.permissions@ oup.com. 
It was based on a systematic root-and-branch review of company law that the Labour Government pitched as the most extensive reform of company law for 150 years. ${ }^{3}$

The Companies Bill was introduced in the House of Lords on 4 November 2005. ${ }^{4}$ After a long journey through the Houses, Royal Assent was given on 8 November 2006 and implementation occurred on a staggered basis with the final phase of implementation only occurring on 1 October 2009. ${ }^{5}$ Staggered implementation was designed not only to allow companies time to make the necessary preparations but also to allow for the creation and introduction of an important underpinning framework of systems and forms at Companies House.

Seven years after the enactment of the consolidating and reforming Companies Act 2006 , it is appropriate to look back on that effort and assess the value of that legacy to the statute book. ${ }^{6}$ What follows focuses on providing a brief contextual understanding of the codification process by considering the review process leading to the Companies Act 2006. This involves identifying the underlying policy objectives as well as the manner of realizing them in primary and secondary legislation. Some aspects of statutory drafting and interpretation are also considered including an assessment of aspects of the codification of directors' duties and judicial handling of certain points of statutory interpretation which have arisen under the 2006 Act. To begin, it is important to place the enactment of the Companies Act 2006 in context as a well-ordered if mammoth piece of legislation which followed an extensive review and reform process. However, an understanding of the historical development of the framework of company legislation in the 19th and 20th centuries is also important to assessing the achievements of the 2006 Act.

\section{FORMATIVE COMPANIES LEGISLATION AND THE REACTIVE REVIEW PROCESS}

Key legislative developments establishing a foundational company law statutory structure occurred in the mid-19th century and early 20th century. Nineteenth century legislation was largely facilitatory in keeping with the laissez-faire approach of the Victorian era. Against the backdrop of the Industrial Revolution, companies legislation provided the public company as a vehicle for large-scale capital investment in public companies to drive major industrial development. A major landmark was the enactment of the Joint Stock Companies Act 1844 which provided for incorporation by registration of a deed of settlement, while the Limited Liability Act 1855 introduced the concept of limited liability. The Joint Stock Companies Act 1856 introduced the modern corporate governance framework in abolishing the deed of settlement and introducing the memorandum and articles of association as the constitutional documents of the company. These various effects were consolidated in the Companies Act 1862. The private company was formally introduced by section 37 of the Companies Act 1907 although it had been informally recognized before then.

\footnotetext{
Modernising Company Law Cm 5553-I (2002) at p. 16.

The Bill started life as the Company Law Reform Bill but its title was later changed to the Companies Bill. A few provisions of the Companies Act 2006 remain uncommenced: section 327(2)(c) and section 330(6)(c).

On the process leading up to the enactment of the Companies Act 2006 see R. Goddard, 'Modernising Company Law': The Government's White Paper', 66 MLR 402 (2003); P. Bovey, 'A Damn Close Run Thing - The Companies Act 2006', 29 Stat L Rev 11 (2008).
} 
Once the fundamentals of the company law statutory structure were in place, the pattern which pertained from the early to the late 20th century was one of cyclical review designed to achieve piecemeal reform and consolidation but nothing more substantial. The key policies of company law were established early in the foundational legislation and carried through to later legislative vehicles and there was a tacit assumption that any review that was carried out was largely tinkering around the fringes rather than anything more radical which would go the heart of the policy underpinnings of the company law framework. For much of the 20th century, the pattern in relation to company law was for the Board of Trade to appoint a Committee to review company law, approximately every 20 years. ${ }^{7}$ The process was reactive, leading to reforming legislation followed by consolidation of company legislation into a new principal Act. These reviews largely resulted in additional regulatory measures being imposed without any fundamental policy review of either the aims of company law or a re-evaluation of its adaptability for contemporary business life. ${ }^{8}$

The pattern of review changed somewhat in the process which led to the Companies Act 1985. The Companies Act 1985 was designed as a consolidating measure in relation to the Companies Acts 1948-83 without inclusion of major amendments. In order to be able to proceed as a straight consolidation measure, certain amendments proposed by the Law Commissions ${ }^{9}$ were dealt with beforehand. ${ }^{10}$ The Act included an unofficial table of derivations at the end. The legislation which prevailed after the Companies Act 1985 became more complex. The decision was made to separately house securities regulation and financial services legislation in stand-alone legislation which stood apart from its company law counterpart. ${ }^{11}$

\section{A NEW INCLUSIVE REVIEW PROCESS}

For the process of reviewing the operation of the Companies Act 1985, an independent Company Law Review was established to report to Government. Launched by Margaret Beckett at the Department of Trade and Industry (DTI) in 1998, the Company Law Review was led by a Steering Group consisting of representatives from the DTI, the Hon Mrs Justice Arden Dame Commander of the Order of the British Empire (former Chairman of the Law Commission), a broadcaster and journalist, an economist and company chairmen. It also had a consultative committee and working groups which included outside experts. This process was also fed into by the work of the Law Commissions. ${ }^{12}$ The Company Law Review engaged in consultation on the

Greene Committee Report (1925) leading to the Companies Act 1929; Cohen Committee Report (Cmd 6659 1945) leading to the Companies Act 1948; Jenkins Committee Report (Cmnd 1749 1962) leading to a number of disparate implementing measures in companies legislation of 1967, 1980, and 1981.

8 For an acknowledgment of these shortcomings, see Company Law Review Modern Law for a Competitive Economy (1998) at para. 2.5.

Law Commission and Scottish Law Commission Amendment of the Companies Acts 1948-1983 (1983); Law Commission and Scottish Law Commission Further Amendments of the Companies Acts 1948-1983 (1984).

10 Companies Acts (Pre-Consolidation Amendments) Order 1984 (SI 1984/134); Companies Acts (Pre-Consolidation Amendments) (No.2) Order 1984 (SI 1984/1169).

11 This was achieved initially though the enactment of the Insolvency Act 1985 and the Insolvency Act 1986 and the Financial Services Act 1986. The hive-off policy continued thereafter with legislation such as Part 10 of the Enterprise Act 2002.

12 Law Commission Shareholder Remedies (LCCO142, 1996), (LC246, 1997); English and Scottish Law Commissions Company Directors: Regulating Conflicts of Interests and Formulating a Statement of Duties (Joint Working Paper LCCP 153, SLC Discussion Paper No. 105, 1998); English and Scottish Law Commissions Company Directors: Regulating Conflicts of Interests and Formulating a Statement of Duties (Law Com No 261, Scot Law Com No 173, 1999). 
basis of publishing nine consultation documents before publishing its final report to Government in July 2001. ${ }^{13}$ The nature of the public consultative process carried out in relation to the work of the Company Law Review was remarkable and yielded many important insights which guided the ultimate direction which the Company Law Review took. Public input did not end there. Once the Government was in receipt of the Final Report of the Company Law Review, it then issued two White Papers ${ }^{14}$ to take the public temperature before proceeding at a policy level to the final stage of preparing instructions for the drafting of the Company Law Reform Bill (later renamed the Companies Bill). Following the publication of draft clauses, the Bill was introduced in the House of Lords on 4 November 2005 and the Royal Assent occurred a little over a year later. Given the protracted nature of review process, it is not surprising that were changes in policy that came about in response to the democratic process of considering the views of the public. The lengthy consultation process was invaluable in ensuring that a workable Bill ultimately emerged.

\section{NAMING THE BEAST: CONSOLIDATION, RESTATEMENT, AND REFORM}

Consolidation of the substance of primary legislation and subsequent amendments into a workable form is often a first step engaged in to tidy the statute book before reform. The Companies Act 2006 was in many respects a consolidation measure but one which proceeded without the tried and tested formula of 'amend first and then consolidate. The tidy up step was omitted and the Companies Act 2006 plunged directly into a dual-pronged consolidation and reform agenda. This model is within what has been described as the 'restate and reform' hybrid. ${ }^{15}$ In this context, restatement in the sense of a rewording and presentation of a new level of clarity shorn of unnecessary bells and whistles was a feature of the clean drafting process. ${ }^{16}$

The Act reworked into clearer language approximately two thirds of the contents of the Companies Act 1985 (which consisted of 747 sections and 25 schedules). The view was taken that it would be convenient to have much of corporate law housed in one primary Act. Thus, when the Bill reached the House of Commons, the text of the consolidated provisions was added to the Bill. Consequently, in large measure, the Act amounted to a 'good housekeeping' measure. A table of origins and table of destinations were made available and were of assistance to those attempting to make sense of what had happened to the prior law.

While restatement of the existing law was a key concern, it is fair to say that, as reflected in the long title to the $2006 \mathrm{Act},{ }^{17}$ the breadth and the scale of the reforms undertaken mark the legislation out as going well beyond simple consolidation or restatement. The ambitious reform agenda can in part be attributed to the energy of

\footnotetext{
Company Law Review Steering Group Modern Company Law for a Competitive Economy: Final Report (2001).

Department of Trade and Industry Modernising Company Law Cm 5553 (2002); Department of Trade and Industry, Company Law Reform Cm 6456 (2005).

A. Samuels, 'Consolidation: A Plea' 26 Stat L R 56, 58 (2005).

Notably, the long title refers to 'restate' rather than to 'consolidate'.

'An Act to reform company law and restate the greater part of the enactments relating to companies; to make other provision relating to companies and other forms of business organisation; to make provision about directors' disqualification, business names, auditors and actuaries; to amend Part 9 of the Enterprise Act 2002; and for connected purposes'.
} 
the Company Law Review. Reforms included, for example, a reform of the derivative action, reforms relating to a company's share capital, relaxed corporate governance rules, and a revised sanctions regime. The twin consolidation and reform objectives were adverted to in the second reading of the Company Law Reform Bill in the House of Commons where Mr Alistair Darling, the Secretary of State for Trade and Industry, referred to it being 'designed to consolidate and update company law'. ${ }^{18}$ The drafting of the Bill also required drafters to keep pace with and react to European Union (EU) legislative developments such as the Takeovers Directive ${ }^{19}$ and the Audit Directive. ${ }^{20}$

What of codification? Although not a term of art, some writers treat reform as inherently part of a codification process in a way that is not involved in consolidation. ${ }^{21}$ Codification is particularly associated with the civil law tradition rather than the common law tradition. ${ }^{22}$ However, in the 19th century, codification became a key strategy for the roll-out of a perfect model of English law in the colonies and was then used in a number of key commercial areas of English law such as the Bills of Exchange Act 1882 and the Sale of Goods Act 1893. It is true that after the 19th century and early 20th century, with some exceptions, codification has not played a particularly prominent role in legal development and valiant codification projects of the Law Commission came to nothing. In 2004, codification in the English legal tradition was said to be in abeyance. ${ }^{23}$ However, the Companies Act 2006 qualifies as a codifying measure. As well as bringing together statutory provisions, in part it also consisted of putting common law principles on a statutory footing. The Company Law Review's view was that in many areas of company law, the statutory code was complemented by case law developments, with many principles being developed by analogy with other adjacent areas such as the law of trusts, the law of agency, and the law of partnership. It stated,

It is inevitable, indeed desirable that ... common law development should generally continue, and the case process has produced great flexibility and depth; but in some key areas it has produced major uncertainties and complexity. The case law is capable of producing robust frameworks of law representing the distilled wisdom of argument over varied factual contexts. But it is not satisfactory that basic rules of business operation and organisation should only be capable of being extracted from a historical examination (often open to costly dispute) of centuries of decisions, often made in widely different and outmoded contexts. In such areas we have judged the right to propose statutory restatements, or codification, often based on significant simplification, or more radical reframing of the common law rules. ${ }^{24}$

19 The Directive on Takeover Bids 2004/25/EC was implemented on an interim basis in The Takeovers Directive (Interim Implementation) Regulations 2006 (SI 2006/1183) and subsequently in Part 28 of the Companies Act 2006.

20 The Directive on Statutory Audits of Annual and Consolidated Accounts 2006/43/EC was implemented in Parts 16 and 42 of the Companies Act 2006 (as amended).

See A. Samuels, 'Consolidation: A Plea' 26 Stat L Rev 56, 59 (2005).

See T. M. Cooper, 'The Common and the Civil Law - A Scot's View' Harv L Rev 468 (1950).

E. Steiner, "'Codification in England” The Need to Move from an Ideological to a Functional Approach - A Bridge too Far?' 25 Stat L Rev 209, 213 (2004).

24 Company Law Review Steering Group Modern Company Law for a Competitive Economy: Final Report (2001) at p. 9-10. 
As discussed below, the challenge of a codification process involving common law principles was exemplified in relation to the difficult task of transferring case law principles on directors' duties to a statutory setting.

Notably, in deciding whether or not proposed reforms should be proceeded with, the Government was alive to the need to take the public temperature. One significant surprise in relation to narrative reporting was the last-minute back-tracking by the Chancellor of the Exchequer on the Operating and Financial Review (OFR) which had been a central plank of the Company Law Review's package of reforms. However, in 2013, the OFR was replaced by provisions requiring a strategic report. ${ }^{25}$ Another set of proposals which did not see the light of day related to the Law Commission's recommendations for simplification of the system for the registration of charges ${ }^{26}$ as public feedback on the recommendations had been mixed. However, following a public consultation by the Department for Business, Innovation and Skills, reforming provisions were introduced into the Companies Act 2006 in 2013. ${ }^{27}$ Furthermore, the diluted concept of enlightened shareholder value encapsulated in section 172 of the Companies Act 2006 whereby directors were required to 'take into account' the interests of stakeholders such as employees, the community, and the environment, while acting to promote the long-term success of the company was considered by many to be purposely constructed as a damp squib which would appease stakeholders but not offend business.

\section{UNDERLYING PHILOSOPHY}

A decade after the Companies Act 1985, zeal for the consolidation and reform of company law re-emerged, showing that a future-proof Act is a Utopian concept. The review process leading up to the Companies Act 2006 was designed to address the charge that piecemeal reform rather than root-and-branch reform based on a clear underpinning philosophy was inadequate and at a global level had left the United Kingdom out in the cold, lagging behind its common law counterparts in Canada, Australia, and New Zealand who had shiny new companies legislation which had moved with the times by casting off anachronistic shackles of history. As the Company Law Review noted in its meaningfully titled report Modern Company Law for a Competitive Economy,

Our current framework of company law is essentially constructed on foundations which were put in place by the Victorians in the middle of the last century. There have been numerous additions, amendments and consolidations since then, but they have created a patchwork of regulation that is immensely complex and seriously out of date. ${ }^{28}$

When the DTI announced the Company Law Review, it made it clear that while it was expecting a thorough review, this would not involve throwing the baby out with the bathwater where the applicable rules were fit for purpose.

\footnotetext{
25 The Companies Act 2006 (Strategic Report and Directors' Report) Regulations 2013 (2013 No. 1970) requiring directors of quoted companies to report on social and environmental duties.

Law Commission Company Security Interests (Law Com No. 296) (2005).

Companies Act 2006 (Amendment of Part 25) Regulations 2013 (SI 2013/600).

Company Law Review Modern Company Law for a Competitive Economy (1998), Foreword.
} 
At the second reading of the Company Law Reform Bill in the House of Commons, Mr Alistair Darling, the Secretary of State for Trade and Industry, said that the Bill 'deals with better regulation, shareholder engagement and a long-term investment culture, which is particularly important. It also provides for some flexibility in the future.29 Major themes were the need to be more responsive to business needs and to replace a piecemeal and inaccessible framework with a logically structured and readable structure which would stand the test of time. The hope was that world-leading legislation would result.

\section{(a) Better Regulation: 'Think Small First'}

A clear policy aim was to fundamentally restructure companies legislation so that it put the needs of private companies first, reflecting their greater magnitude in contrast to times past. The Companies Act 2006 represented an opportunity to reslant companies legislation so that it was geared towards the reality of how business was being done. Initially, the birth of company had been at the discretion of the Crown. Later, the more ready possibility of incorporation was opened up but companies legislation in the 20th century continued to place the public company out front as the primary company model, while the private company was in the background. The layout of legislation including the Companies Act 1985 continued a model of assuming the public company as the default model ${ }^{30}$ with provisions in relation to private companies tucked away as a variant rather than reflecting the reality that in fact in the terms of numbers, the private company was the model of choice in most instances. ${ }^{31}$ In the 19th century, the public company did have a major role to play as a vehicle for companies engaged in projects requiring large-scale investment to fund capital-intensive projects such as railway laying. However, in the 21st century, it was considered appropriate for companies legislation to be more explicitly designed to serve the needs of small companies. Underlying this was the realization that a less protective regime is needed for private companies which, unlike public companies, are not permitted to offer their shares freely to the public. The Company Law Review and the Government therefore operated with the 'Think Small First' mantra which involved simplifying where possible the legal framework for businesses to incorporate and run.

The 2002 White Paper articulated why reform was needed in the interests of business efficiency:

Company law has a direct impact on enterprise. It can actively promote and encourage enterprise - or hold it back. The Government is strongly committed to promoting enterprise and believes that company law reform has an important part to play in making it as easy as possible to start and run companies while maintaining adequate safeguards against abuse. ${ }^{32}$

30 Thus in section 1(3) of the Companies Act 1985 the private company was defined in terms of its big brother the public company: 'a private company is a company that is not a public company'.

31 The register comprises just $0.3 \%$ public companies: Companies House Statistical Tables on Companies Registration Activities 2012/2013 (2013), Table A2 at p. 7.

32 Modernising Company Law Cm 5553-I (2002) at p. 11. 
In introducing the Bill in the House of Lords, Lord Sainsbury, the Parliamentary Under-Secretary of State at the DTI, underlined the functionality of the Bill as being responsive to companies doing business. This involved a legislative approach which was cognizant of the fact that 95 per cent of companies were small limited liability companies. The primary approach was 'that company law should be primarily enabling or facilitative .... ${ }^{33}$ This meant providing a flexible framework which removed unnecessary regulatory burdens, particularly for small companies. Essentially, the view was that the law should support business rather than hinder it. This enabling approach was seen in facilitating informal unanimous decision-making, thus recognizing that formal company meetings are not necessarily the norm in business life; allowing the adoption of a single document constitution instead of the memorandum and articles of association; reducing the accounting and audit burden on small companies; reforming the capital maintenance rules; and reforming sanctions to make them more proportionate. Flexibility was provided in making it easier to do business by the Act frequently adopting provisions which are enabling rather than mandatory in nature. Thus, for example, if companies wanted to continue to adhere to familiar requirements such as the 1985 model articles, ${ }^{34}$ rather than move to new model articles, they were permitted do so.

\section{(b) The Plain Language Agenda}

Consolidation afforded the opportunity for textual reappraisal with the accessibility goal firmly in mind. It was expected that, where possible, existing principles that were being retained would be reframed into plain English so as to be comprehensible to the non-specialist reader and to remove outdated verbiage and concepts. ${ }^{35}$ The case for plain speaking and easy access was articulated by the Government as follows:

The law needs to be clearer, more certain and more accessible. The present framework has developed through a series of partial reviews and piecemeal alterations. This has made it increasingly bulky and complex. The way it is written makes it particularly difficult to identify those provisions which apply to smaller companies. For example, the main rules on accounts are set out in one place with no indication that there is any simpler provision elsewhere for smaller companies. It takes another 20 pages to find these - and it would be easy to overlook them. ${ }^{36}$

It is fair to say that although bulky, the 2006 Act is a sleek model of logical, ordered sequences, for the most part written in language which is as accessible as company law language can be. A major achievement of particular use to new companies was the rewriting of the model articles for companies into more user-friendly language, stripped of arid and outdated technicalities. ${ }^{37}$

\footnotetext{
Company Law Review Steering Group Modern Company Law for a Competitive Economy: Final Report (Vol. I) at p. xi. Companies (Tables A-F) Regulations 1985 (SI 985/805).

Company Law Review Modern Company Law for a Competitive Economy (1998), Foreword.

Modernising Company Law Cm 5553-I (2002) at p. 11.

The Companies (Model Articles) Regulations 2008 (SI 2008/3229).
} 


\section{(c) A Long-Term Investment Culture}

As noted above, one of the most contentious provisions of the Companies Act 2006 was section 172 with its cryptic concept of enlightened shareholder value. As a product of compromise, it is not considered to displace the usual profit maximization model under which companies operate. What it did do was create uncertainty and mixed views on what it actually meant for companies. ${ }^{38}$ The independent review of the Companies Act 2006 which was commissioned by the Department for Business, Innovation and Skills indicated that the provision of guidance on how directors could show compliance with section 172 would be welcomed by the business community. ${ }^{39}$

\section{(d) Shareholder Engagement}

The objective of shareholder engagement can be criticized for being aspirational rather than something that could realistically be achieved by legislation. It would require a societal shift given that the battle is for hearts as well as minds. A proposal that institutional investors disclose their voting was voted out at Lords stage. The reform of the derivative claim in Chapter 1 of Part 11 of the Act was designed to ensure that the relevant procedures were fairer and more easily understood and that it would not be available in frivolous cases where it would not be in the interests of the company to commit it to litigation. In practice, anecdotal evidence suggests that the reformed statutory derivative claim has not been regarded as a success given the asymmetries of information and the issue of costs which work against a shareholder bringing an application.

\section{CODIFICATION OF DIRECTORS' DUTIES}

The micro-story of the codification of directors' duties within the framework of the Companies Act 2006 is a tale worth recounting. ${ }^{40}$ The inclusion of a statutory statement of directors' duties represented a volte face at policy level on a hesitancy exhibited by many review committees as to the wisdom of taking such a step. In 1926, the Greene Committee thought that 'any attempt by statute to define the duties of directors would be a hopeless task. ${ }^{41}$ Several decades later the Jenkins Committee considered that attempting an exhaustive definition of the duties of directors would be unwise. ${ }^{42}$ Instead a preference was exhibited for statutory supplementation of the general duties. ${ }^{43}$

Nonetheless, both the Law Commissions ${ }^{44}$ and the Company Law Review embraced this as a means of delivering transparency and accessibility, particularly to

The literature which section 172 with its concept of enlightened shareholder value has generated is vast. For a good discussion on the genesis of the concept at policy level, see A. Keay, 'Enlightened Shareholder Value, The Reform of the Duties of Company Directors and the Corporate Objective' LMCLQ335 (2006).

39 Infogroup/ORC International Evaluation of the Companies Act 2006 (Vols. I, Department for Business, Innovation and Skills, 2010) at p. 162.

40 See generally D. Ahern, 'Directors' Duties, Dry Ink and the Accessibility Agenda' 128 LQR 114 (2012).

41 Report of the Company Law Amendment Committee ('the Greene Committee Report') Cm 2657 (1926) at para. 46.

42 Report of the Company Law Committee ('the Jenkins Committee Report') Cmnd 1749 (1962) at para. 87.

43 Before the enthusiasm of the Law Commissions and the Company Law Review, attempts at codification in the Companies Bills 1973 and 1978 proved abortive.

44 English and Scottish Law Commissions Company Directors: Regulating Conflicts of Interests and Formulating a Statement of Duties Joint Working Paper LCCP 153, SLC Discussion Paper No. 105 (1998); English and Scottish Law Commissions, Company Directors: Regulating Conflicts of Interests and Formulating a Statement of Duties (Law Com No 261, Scot Law Com No 173, 1999). 
the director class. In codifying hitherto equitable and common law rules on directors' duties in Chapter 2 of Part 10 of the Act, the United Kingdom followed a modern trend in other common law jurisdictions such as Canada, Australia, and New Zealand which had unveiled revamped companies legislation. This comparison led the Commissions to conclude that 'a modern UK Companies Act would look odd'45 without a statutory statement of duties. Although the key objective focused on by the English and Scottish Law Commissions, the Company Law Review Steering Group and the Government was improved accessibility, as noted elsewhere, there was a tacit assumption of a positive correlation between accessibility of the law and compliance. ${ }^{36}$

In Eastford v. Gillespie, Lord Hodge regarded the statutory statement as intended to make those duties more accessible to commercial people. ${ }^{\prime 7}$ Although the existence of a statutory statement of duties can be considered to have a salutary effect in relation to drawing attention to the fact that legal duties exist, beyond that there are reasons to doubt whether the accessibility agenda could really be delivered on to any significant degree as regarded the lay user. The Regulatory Impact Assessment (RIA) maintained that significant cost savings concerning professional advice based on the roll-out of a transparent statutory statement of duties. ${ }^{48}$ This notion that legal advice would prove unnecessary was misjudged. To begin with, the necessarily general nature of the duties provides no guidance as to how a director might be expected to act in a specific situation. The posited costs savings adverted to in the RIA also failed to take into consideration the legal uncertainty created by infelicitous and cryptic wording in a number of provisions. The continuing controversy surrounding the embodiment of the concept of 'enlightened shareholder value' in section 172 of the Companies Act 2006, a diluted provision drafted to reflect a need to be all things to all people, shows that the import of the provision and how best it should be complied with is far from clear. The accessibility agenda is also militated against by the 'partial codification' ${ }^{49}$ approach since non-codified duties other than the seven duties codified in the Act exist as a trap for the unwary. In this regard, it would perhaps have been helpful if the legislation expressly made the reader aware that uncodified duties potentially exist. ${ }^{50}$

Of particular note for those interested in parsing legislation is the unfortunate legislative quagmire concerning interpretation of the statement of duties created by inconsistencies which are difficult to resolve. Section 170(3) of the 2006 Act states,

The general duties are based on certain common law rules and equitable principles as they apply in relation to directors and have effect in place of those rules and principles as regards the duties owed to a company by a director.

45 English and Scottish Law Commissions Company Directors: Regulating Conflicts of Interests and Formulating a Statement of Duties (Law Com No 261, Scot Law Com No 173, 1999) at para. 4.43.

46 D. Ahern. 'Directors' Duties, Dry Ink and the Accessibility Agenda' 128 LQR 114 (2012).

$47 \quad$ [2009] CSOH 119, [9].

48 Department of Trade and Industry Company Law Reform Cm 6456 (2005) at p. 276.

49 Ranson v. Customer Systems Plc [2012] EWCA Civ 841, [20], per Lewison L.J.

so As it stands, the Act only makes reference to an additional uncodified duty to consider the interests of creditors (section $172(3)$ ). However, see also section 170 (3) of the 2006 Act which provides that the statutory general duties are based 'on certain common law rules and equitable principles'. 
However, confusingly the departure from old to new which is contemplated by section $170(3)$ requires some rethinking when one reads section $170(4)$ which states,

The general duties shall be interpreted and applied in the same way as common law rules or equitable principles, and regard shall be had to the corresponding common law rules and equitable principles in interpreting and applying the general duties.

The combination of these provisions is quixotic and negates the legal certainty which would be desirable in relation to a codification. Furthermore, the formula is not one which finds an analogue in other common law world statutory statements of directors' duties. In Towers v. Premier Waste Management, Mummery LJ regarded the effect of section 170(4) as being that section 170(3) 'did not consign the replaced rules and principles to legal history.' ${ }^{51}$ This perspective is also seen in Killen v. Horseworld Ltd, where Robinson J noted that "[a]lthough the new code is expressed to be "in place of" the existing non-statutory regime, that regime remains of more than merely historical significance by virtue of section $170(3)$ and (4), ${ }^{52}$ Further interpretative complexity is added by the accompanying Explanatory Notes which regard section $170(4)$ as permitting future developments in the law of trusts and agency to be taken into account in the interpretation and application of the duties. ${ }^{53}$

Notably, in the small volume of cases on directors' duties after the 2006 Act, there has been a worrying judicial tendency to equate the new provisions with the prior law and to simply turn to prior case law in place of beginning with a textual examination of the relevant statutory provision. ${ }^{54}$ However, in Killen v. Horseworld Ltd, the court took a refreshing approach by acknowledging that the statutory provisions heralded in a firmer position that that which had prevailed at common law in relation to opportunities which a director became aware of before exiting the company. ${ }^{55}$

\section{ASSESSING THE DURABILITY OF THE LEGISLATION}

(a) Use of Statutory Instruments

During the review process some thought was given in relation to how best to achieve flexibility for the future. One of the ideas behind the codification process was that key principles would be set out in the primary legislation and that other rules which would be more likely to require change would be better placed in secondary legislation. It was considered that the use of statutory instruments for more detailed aspects ${ }^{56}$ would help to avoid overnecessity for amendments to the primary legislation and would also enable adjustments to be made to reflect changing technological requirements. Already more than 100 statutory instruments have been made under the Companies Act 2006.

\footnotetext{
[2011] EWCA Civ 923, [5]. See also Stone \& Rolls Ltd (in liquidation) v. Moore Stephens (a firm) [2009] UKHL 39, [224]. [2012] EWHC 363 (QB), [63].

Department of Trade and Industry Companies Act 2006 Explanatory Notes (2006) at para. 305.

See Gregson v. HAE Trustees Ltd [2008] EWHC 1006 (Ch); Eastford Ltd v. Gillespie [2009] CSOH 119; Thermascan Ltd v. Norman [2009] EWHC $3694(\mathrm{Ch})$.

[2012] EWHC 363 (QB), [86].

56 See eg The Large and Medium-sized Companies and Groups (Accounts and Reports) Regulations 2008 (SI 2008/4110).
} 


\section{(b) Amendments}

There have been some textual changes. For example, section 80 of the Enterprise and Regulatory Reform Act 2013 inserted a new Chapter 4A into the 2006 Act dealing with directors' remuneration policy. As always, subsequent non-textual amendments provide a challenge. ${ }^{57}$ Some not insubstantial amendments have occurred on foot of EU directives. Thus, for example, Part 13 of the Act was heavily amended by statutory instrument ${ }^{58}$ in order to implement the Shareholders' Rights Directive. ${ }^{59}$ At the time of writing, a number of prospective amendments and repeals are designed to take effect at a specified future date or at a date which has yet to be appointed.

\section{(c) Judicial Decisions}

In a common law jurisdiction, the interplay between a legislative 'code' and the courts is an important one as codification is more notional than its civil law counterpart. As Donaldson J. observed in Corocraft Ltd v. Pan American Airways $I n c^{60}$ on the role of judges, ' $[t]$ hey are not legislators, but finishers, refiners and polishers of legislation which comes to them in a state requiring varying degrees of further processing. ${ }^{61}$ Indeed, as Lord Scarman astutely observed in his reflections upon codification, '... the very first decision interpreting a section of the code would begin the reinstatement of judicial decision as a law-shaping force.62 Given that we are not talking about a code in the formal civil law sense of an exhaustive point of reference, it is apt to refer to the admonition of Chalmers, the early architect of codification in the 19th and early 20th century, that ' $[\mathrm{w}] \mathrm{e}$ cannot escape from the common law, and we should not try to do so. ${ }^{63}$ In cases which have arisen after the enactment of the Companies Act 2006, the courts have been ready to refer to both the reports of the Law Commission and of the Company Law Review as an aid to understanding the effect of provisions. This is seen, for example, in relation to the statutory derivative claim. ${ }^{64}$

An important issue in relation to codifying legislation concerns the extent to which prior common law principles will continue to apply. The question is whether common law doctrines and principles can be regarded as surviving - there is a tension here between regarding the new legislation as the pre-eminent law-shaping force and bowing to the long-established nature of common law doctrine.

The courts have confirmed that even where reforms were affected by the 2006 Act, as a matter of statutory construction, the prior common law will only be regarded as being displaced where this is the clear express or implied statutory intention. This point came up in Re Fort Gilkicker Ltd; Universal Project Management Services Ltd v. Fort Gilkicker Ltd. ${ }^{65}$ Briggs $\mathrm{J}$ had to consider whether, given that the common law previously appeared to permit a

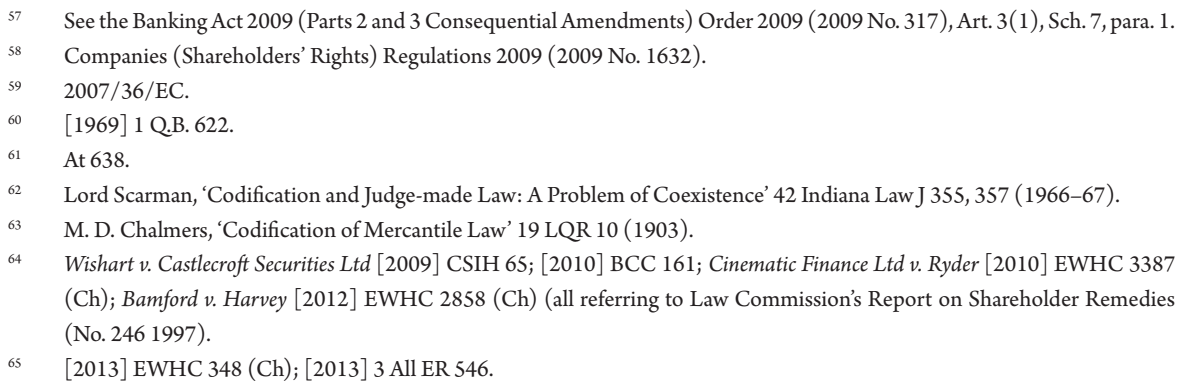


derivative action by a member of a parent company in wrongdoer control ${ }^{66}$ (a 'multiple derivative action'), it could be said that this remained an implicit possibility under Part 11 of the Companies Act 2006. Briggs J relied on Dyson LJ (as he then was) in Islington London BC v. $U c k a c^{67}$ in stating that the effect of the provisions of the 2006 Act upon prior common law in relation to the derivative action was a question of statutory construction and a statute could only be construed as displacing common law principles including rights if this was achieved expressly or was a necessary implication. Two competing interpretative approaches were presented by counsel, neither of which were regarded by Briggs J as obviously that intended by Parliament. This gave rise to a rather unpalatable dilemma outlined by him as follows:

... a main purpose of the codification of derivative claims in Ch 1 was to remove what were regarded (at least by the Law Commission in its report on shareholder remedies) as complicated, unwieldy and obscure provisions of the applicable common law and to replace them with a clear and transparent code. A conclusion that what Parliament in fact achieved in 2006 was to place a statutory code for derivative claims by members of the wronged company alongside a continued obscure, complicated and unwieldy common law regime for derivative claims by others does not commend itself as an exercise in common-sense. Conversely, a conclusion that by narrowly defining locus standi for all company derivative claims to members of the wronged company Parliament abolished a convenient procedural device for doing justice in cases of wrongdoer control, in a modern context where multi-layered corporate structures with holding companies and subsidiaries are ever more common, hardly commends itself as an exercise in justice. There is, on the face of it, no persuasive reason why Parliament should have wished to provide a statutory scheme for doing justice where a company is in wrongdoer control, but none where its holding company is in the same wrongdoer control. ${ }^{68}$

Briggs J referred to academic views which were evenly divided on the question of whether the post-2006 landscape permitted multiple derivative actions. In one camp, there were those who regarded the multiple derivative action as having been implicitly abolished. ${ }^{69}$ The other school of thought was that the issue of multiple derivative actions was not addressed by the 2006 Act and thus survived. ${ }^{70}$ Extracts from the Company Law Review Steering Group's reports were not found to advance resolution of the issue. In the end, the judge concluded that on balance the Act did not remove the multiple derivative action based on regarding the so-called multiple derivative action as simply a species of the derivative action and designed to avoid injustice. This aspect of

66 Wallersteiner v. Moir (No 2) [1975] 1 All ER 849; Hallev. Trax BW Ltd [2000] BCC 1020, Truman Investment Group v. Societe General SA [2003] EWHC 1316(Ch); and Airey v. Cordell [2006] EWHC 2728 (Ch).

67 [2006] EWCA Civ 340 [28].

68 At [34].

69 D. D. Prentice and A. Reisberg, 'Multiple Derivative Actions' 125 LQR 209 (2009); P. Koh, 'Derivative Actions “Once Removed”' JBL 101 (2010); S. Goo, 'Multiple Derivative Action and Common Law Derivative Action Revisited: A Tale of Two Jurisdictions' 10 JCLS 255 (2010); Lord Millett Gore-Browne on Companies Bulletin (2010); Charlesworth's Company Law (18th ed.) at p. 518.

70 See D. Lightman, 'Two Aspects of the Statutory Derivative Claim' LMCLQ142 (2011); Hollington on Shareholders' Rights (6th ed., 2010) at para. 6-28. 
the old common law device was therefore regarded as remaining unaffected since it was not covered by the Companies Act 2006. Briggs J stated,

\begin{abstract}
Applying the well-established relevant principle of construction, Parliament did not expressly abolish the whole of the common law derivative action in relation to companies, even though by implication from the comprehensiveness of the statutory code it did do so in relation to derivative claims by members (as defined) of the wronged company. Beyond that, the assertion that the remainder of the common law device was abolished fails because abolition was neither express nor a clear or necessary implication. ${ }^{71}$
\end{abstract}

This illustrates the complexities that can arise in a statutory landscape where full codification cannot be presumed.

\title{
8. CONCLUSION
}

Codification of the law provides an important opportunity to provide a clear statement of legislative and judicial principles while also permitting an opportunity for reform. The review and drafting process leading up to the Companies Act 2006 embraced all of these aspects and delivered a formidable combination of carefully arranged and well-drafted heavyweight primary legislation. Later, a suite of statutory instruments emerged as supporting cast. Preceded by a wide-ranging review of the fundamental objectives and structure of company law, the legislation reframed and updated familiar statutory principles, while adding important reforms and some codification of common law, most notably in the area of directors' duties.

In its final report to Government, the Company Law Review stated ' $[\mathrm{w}] \mathrm{e}$ believe that our recommendations represent a major reworking of the whole framework of company law which meets the aim of making it fit for the new century.72 Looking back with the benefit of hindsight, it is fair to say that this objective has been achieved-a powerful workhorse for the 21 st century has been delivered. Nonetheless, the perfect vision afforded by hindsight will always admit some quibbles. Some stakeholders consider that the Act did not go far enough, particularly having regard to the flawed realization of the concept of 'enlightened shareholder value'. Some discordant notes are to be expected from mammoth legislation of this kind which is highly technical in content. We must be realistic about what we can expect from legislation, particularly legislation which is designed to regulate the corporate form. In a common law country, codification in a real sense is not achievable; we should not expect an exhaustive code of the type beloved of our common law neighbours. The wheels of commerce do not stop turning nor should our legislation. There are already a raft of amending provisions and a labyrinth of statutory instruments to contend with. The durability of the Companies Act 2006 remains to be seen. Bearing in mind that no legislation is set in stone; the best we can hope for is that UK companies legislation will continue to be both reactive and responsive.

At [46].

Company Law Review Steering Group Modern Company Law for a Competitive Economy: Final Report (2001) at p. vii. 